\title{
Study on the Application and Practice of Blended Teaching Mode in Introduction to Maoism and Chinese-featured Socialism Ideology Applied Technology of Database based on Activity-oriented Approach
}

\author{
Jian Ai \\ Xi’an Peihua University, Xi’an, Shaanxi, China
}

Keywords: activity-oriented; bended teaching mode; Maoism and Chinese-featured Socialism Ideology Applied Technology of Database

\begin{abstract}
Connotation and characteristics of blended teaching mode based on activity-oriented approach have been analyzed in this paper. With the example of "Introduction to Maoism and Chinese-featured Socialism Ideology Applied Technology of Database”, this paper also discusses how to realize the cooperation between teachers and students and improve the sense of obtaining from students for the course by virtue of blended teaching mode of online and offline.
\end{abstract}

\section{Connotations and characteristics of blended teaching mode based on activity-oriented approach}

With the advent and wide application of age of big data, the application and practice of information technology in college teaching has dramatically promoted the educational reform in China. National Educational Technology Guides for Teachers in Higher Education of 2010 emphasize to strengthen the teachers' recognition and effective application of teaching reform with the support of information technology tools. In 2016, President Xi Jinping pointed out that "Internet information technology has been incorporated in economic and social life and it is the information artery for the national development”, which requires college teachers to adapt to the development of times, actively practice the strategic idea of "Internet power strategy" put forward by Xi Jinping, make full use of such modern information technology as Internet, Cloud Computing and Big Data to update teaching concepts combining curricular and extracurricular teaching activities, change traditional cramming classroom teaching mode, create blended teaching mode based on activity-oriented approach with the cooperation of teachers and students as the center at the same time, and realize the "all-out, thorough, and all-round education and cultivation of students".

At present, blended teaching mode based on activity-oriented approach has been the main trend of information-based teaching, which requires teachers to design curricular and extracurricular identification programs combing characteristics of psychological cognition of students based on the constructivism theory according to special topic teaching contents established. Under the guidance of teachers, students can set up studying group, work cooperatively to accomplish the online and offline identification programs, so as to mobilize the initiative, enthusiasm, creation and participation of students as the subject and to realize the understanding of teaching contents and the innovation in internalization and application of knowledge.

\section{Introduction to Maoism and Chinese-featured Socialism Ideology Applied Technology of Database and blended teaching mode based on activity-oriented approach}

Introduction to Maoism and Chinese-featured Socialism Ideology Applied Technology of Database (referred as "the course"), is the most important course in ideological and political theories course in college, and a compulsory course of public political theory for all undergraduates in the whole college. It covers 96 class hours in total, 56 of which are for theory and 40 for practice. The objective of this course is to "take the localization of Marxism in China as the main line, help students to understand and master theoretical results formed in the localization of Marxism in China accurately and systematically; have a deeper understanding of the historical process, historical 
changes, and historical achievements of the revolution, construction, and reforms carried out by the people and led by the Chinese Communist Party; have a more thorough understanding of the basic theories, basic lines, and strategies that the Chinese Communist Party has upheld in the new era; and train students to establish a historical perspective, world vision, national conditions awareness and problem awareness, and enhance the ability to identify problems, analyze problems and solve problems with the use of positions, perspectives and methods of Marxism”.

Educational reforms shall be implemented with great power in order to realize the teaching objective and requirement above and to improve the effectiveness of the course. Therefore, blended teaching mode based on activity-oriented approach in educational reform should be carried out based on respecting the basic teaching contents and requirements of this course, with the blended teaching mode of online and offline, to realize the teaching objectives in the following:

Firstly, to closely relate theory to practice, classroom to society, and to train the ability of learning and applying knowledge and analyzing and solving problems with theory.

Secondly, to increase the rate of attendance and participation in the class, curricular and extracurricular vitality and effectiveness, lead students to study and conduct research independently, and to apply and internalize knowledge to become self-competence, improve the teaching quality and realize teaching objectives.

Thirdly, to facilitate the realization of objectives of knowledge, competence, emotion, attitude and value of students.

4thly, to cultivate the spirit of team-work with the team-work cooperation, create a harmonious, democratic, equal and competitive teaching environment, and cultivate the ability of cooperation, practical research and critical thinking, the perspective of getting insight into problems and methods of solving problems, especially to cultivate the critical thinking.

\section{The design of blended teaching mode based on activity-oriented approach}

\subsection{Guideline and thinking of curriculum design}

In curriculum design, we take the cultivation of political accomplishment, independent thinking, knowledge obtaining and independent learning, knowledge application and innovation, international vision and exchanges, presentation and communication, commitment and team-work and the increase of sense of obtaining as the aim; with the orientation of the application of the course, and the method of integrating professional requirements, rely on 4 special topics, apply PBL teaching, blending majors, blended teaching and practical teaching, design 7 identification programs and focus on the cultivation of the above 7 competence and abilities.

After the integration of curriculum design, the original contents of 14 chapters in the course has been integrated into such three theories as Maoism, "socialist theory with Chinese characteristics", and "the theory of socialism with Chinese characteristics of Xi Jinping in the New Era", 4 special topics such as Maoism, "Theories of Socialist Revolution, Transformation, Preliminary Exploration", "socialist theory with Chinese characteristics of Deng Xiaoping, Jiang Zemin, and Hu Jintao", and "the theory of socialism with Chinese characteristics of Xi Jinping in the New Era", 7 identification programs such as I love, I am the host, knowledge contest, classic reading, in-depth discussion, short scenes, innovative work, and Visualization Competition of the course, so as to correspond to the 7 competence and abilities. The contents transformation of 14 chapters to 4 special topics realizes the transformation from teaching material system to teaching system; the close relation of 4 contents and 7 identification programs realizes the task of teaching system; the implementation of 7 identification programs advances the improvement in 7 competence and abilities and the competence trend of task system.

The cooperation between teachers and students as the center is strengthened in the design of curriculum implementation process. Teachers assign tasks, students refer to news and materials, analyzing, discuss and arrange work in group, teacher guide, various works are produced, and students PK in and after the class by various ways. Finally, teachers and students assess and conclude together, and teachers or experts give a conclusion to respond to improve the 7 
competence and abilities. As for teaching contents, from 12 chapters to 7 special topics, the curriculum design become easier; as for teaching situation, from China Stands Up, to China Gets Rich, to China Strengthens, it is from far to near; as for identification programs, from I love, I am the host to visual competition, it becomes more complex; as for competence of students, from recognition, analysis, internalization, application to innovation, it becomes higher.

\subsection{The design of blended teaching mode based on 7 activities-oriented approach}

After making clear the contents of the curriculum, we can establish the platform with the aid of Mosoteach, online network and offline classroom blended. Specific procedures are in the following:

(1) Before the class(online and offline blended): The teacher need to create a class number first, inform student to join it, upload PPT, pictures, videos, classic reading materials or links, topics for in-depth discussion corresponding to chapters in the APP resource. Students can download those to learn and the teacher can remind students who don't watch and learn in time according to the learning record on the APP. In addition, the teacher also need to upload knowledge contest to the test before the class through PC of the APP, and set assessment contents, key points, assessment objectives for the class; by this online teaching, students can obtain experience as a part of process assessment. Besides, under the guidance of teacher, students cooperate together to take videos and make PPT of those programs to the teacher as a part of process assessment. At the same time, teacher can share those excellent resources with everyone by uploading to the APP.

(2) During the class (online and offline blended): At first, teacher lead students to discuss domestic and foreign news with those videos and to grade to other groups in the activities before the class. Secondly, teacher gives lessons on special topics as main line, and teacher can present scene plays and classic reading videos according to the requirements of teaching contents and objectives to arouse the interests of students to learn. Thirdly, students attend knowledge contest and obtain corresponding credits through activities before the class on the APP, teacher implement differentiated instruction to different classes and different key points with the analysis of the APP to grades of students. To enliven the class atmosphere, knowledge contest also can be carried out in online and offline way. At last, teacher and students reach the in-depth discussion. Representatives of each group present their PPT and teacher and students give assessment to each group representative according to the APP classroom performance, raising hands, racing to be the first to answer a question, member selection and group assessment.

(3) After the class (offline teaching): According to teaching contents and online materials, students independently learn, analyze and think, accomplish innovative works based on the arrangement of the teacher and their major, and attend visual competition under the organizing of teacher, arrangement and cooperation of related departments, and present their innovative work concept and contents, graded and awarded by professional judges. Finally, with the help of relevant departments of news center, results of students can be publicized and the sense of obtaining in the ideological and political theories course will be enhanced.

\subsection{The assessment design of blended teaching mode based on seven activities-oriented approach}

Table 1

\begin{tabular}{|c|c|c|c|c|}
\hline \multicolumn{5}{|c|}{ Process assessment } \\
\hline \multicolumn{2}{|l|}{ Grades } & Assessment contents & Corresponding point & Assessment points \\
\hline \multirow{8}{*}{$\begin{array}{l}\text { Process } \\
\text { assessment } \\
70 \%\end{array}$} & \multirow[t]{2}{*}{$\begin{array}{l}\text { Before the } \\
\text { class }\end{array}$} & I love, I am the host. & 10 & $\begin{array}{l}\text { Political accomplishment, } \\
\text { international vision and exchanges }\end{array}$ \\
\hline & & Classic reading & 10 & \multirow{4}{*}{$\begin{array}{l}\text { Presentation and communication, } \\
\text { knowledge obtaining, internalization } \\
\text { and application, commitment and } \\
\text { team-work }\end{array}$} \\
\hline & \multirow{3}{*}{$\begin{array}{l}\text { During the } \\
\text { class }\end{array}$} & Knowledge contest & 10 & \\
\hline & & In-depth discussion & 20 & \\
\hline & & Scene plays & 15 & \\
\hline & \multirow{3}{*}{$\begin{array}{l}\text { After the } \\
\text { class }\end{array}$} & Innovative works & 20 & \multirow{3}{*}{$\begin{array}{l}\text { Knowledge } \\
\text { independent ap } \\
\text { innovation }\end{array}$} \\
\hline & & Visual competition of the course & 15 & \\
\hline & & Individual value & Extra point & \\
\hline $\begin{array}{l}\text { final-examina } \\
\text { tion } 30 \%\end{array}$ & $\begin{array}{l}\text { final-examina } \\
\text { tion }\end{array}$ & $\begin{array}{l}\text { Assessment of knowledge points in } \\
\text { subjective and objective questions }\end{array}$ & 100 points & $\begin{array}{l}\text { comprehensive } \\
\text { knowledge }\end{array}$ \\
\hline
\end{tabular}




\subsection{The implementation of blended teaching mode based on seven activities-oriented approach}

In the specific implementation of the curriculum, the knowledge competence has been improved by the "I love, I am the host", and the course is filled with the "sense of reality"; "classic reading" strengthens the knowledge competence and increase the "sense of concordance"; "knowledge contest" checks the knowledge competence and increase the "sense of vitality"; "in-depth discussion" improves the political and ability competence and increase the "sense of depth perception"; "scene plays" enhances the knowledge, ability and political competence and increase the "sense of fun"; "innovative works" combines contents of special topics and professional courses and increase the "sense of innovation" because students can well internalize and develop contents of special topics taught by teachers. For instance, creation activities of "One class, One painting” and "One class, One poetry" are carried out in animation major and major in Chinese language and literature. "visual competition" increase the "sense of effectiveness"; we have held the social and scientific micro film competition and produced 473 excellent works focusing on social reality and spreading positive energy; we have held competition of students works in teaching reform of ideological and political theories course and produced the cartoon version and film literature version of contents of 7 special topics. We take the method of all-round and diversified process assessment to lead students to learn in doing and do in learning and increase the effectiveness of the course.

\section{Conclusion}

The application of blended teaching mode of the course based on activity-oriented approach in teaching has realized so many accomplishments. After the curriculum reform, teaching effectiveness has been improved dramatically, and the universal indexes like attendance are higher. There are more characterized indexes with higher specifications, such as the attendance of the cooperation of college and enterprise and discipline competitions. The interests of students, the enthusiasm, the participation and the sense of identity of curriculum value are increasing, and at the same time, the sense of obtaining from ideological and political theories course has been greatly improved.

\section{Acknowledgements}

Subject project: This paper is the staged achievements of school-level education teaching reform research project, "Study on the Application and Practice of Blended Teaching Mode in Introduction to Maoism and Chinese-featured Socialism Ideology Applied Technology of Database based on Activity-oriented Approach” of Xi'an Peihua University in 2017. (Project No. PHY1717).

\section{References}

[1] Implement the Internet power strategy, Report on Current Events (Junior School), 2016, 02.

[2] Introduction to Maoism and Chinese-featured Socialism Ideology Applied Technology of Database, Higher Education Press, 2018 version, P5-6 of Preface. 